\title{
PERAN PEMERINTAH DALAM PERENCANAAN PEMBANGUNAN LAPANGAN GOLF KINTAMANI DENGAN PRINSIP PARIWISATA BERKELANJUTAN
}

\author{
Rila Hilma \\ Hotel Management Department, Faculty of Economic and Communication, BINUS University \\ Jln. K.H. Syahdan No. 9, Palmerah, Jakarta Barat 11480 \\ rila.hilma@binus.edu
}

\begin{abstract}
Planning a tourist destination, some aspects need to be considered concerning government's role, surrounding society, and sustainable development principles. The project of golf court in caldera Gunung Batur must be analysed by some experts. This study aims to anticipate some new troubles that might come up when the construction of golf court begins. Above it all, every study has opportunity to be applied whether by regional or national government, who responsibly takes control of the region, once they approved the project. Based on it, the plan of golf court construction in Kintamani, Bangli regency, Bali Province (as cited by www.bisnisbali.com on $27^{\text {th }}$ January 2011) proposed by Ministre Jero Wacik and approved by the parlement members of DPRD Bangli, concerns the principles of sustainable tourism which could prevent, especially Kintamani region, from deconstructed side effects of the development. This research applies qualitative-descriptive method supported by literature review and news from media, especially online media which are able to provide the actual news from Kintamani region.
\end{abstract}

Keywords: court golf, Kintamani Bali, sustainable tourism, government's role

\begin{abstract}
ABSTRAK
Dalam merencanakan pembangunan destinasi wisata, diperlukan beberapa aspek terkait dengan peran serta pemerintah, masyarakat sekitar, dan prinsip pembangunan berkelanjutan. Wacana pembangunan lapangan golf di kaldera Gunung Batur seyogyanya dipertimbangkan berdasarkan hasil kajian pihak berkompeten. Kajian itu dilakukan untuk mengantisipasi agar tidak menimbulkan masalah baru yang muncul ketika pembangunan lapangan golf dilakukan. Di atas itu semua, segala kajian yang dilakukan akan dapat direalisasikan setelah pemerintah daerah atau pusat menyetujui adanya rencana pembangunan di daerah yang menjadi tanggung jawab mereka. Oleh karena itu, selayaknya rencana pembangunan lapangan golf di Kintamani, kabupaten Bangli, provinsi Bali (seperti yang dilansir oleh www.bisnisbali.com pada tanggal 27 januari 2011) yang disulkan oleh Menteri Jero Wacik dan sudah disetujui oleh kalangan anggota DPRD Bangli, memerhatikan prinsip pariwisata berkelanjutan yang dapat mencegah daerah Kintamani pada khususnya dari dampak-dampak pembangunan yang merusak. Metode penelitian ini adalah kualitatif deskriptif yang didukung oleh kajian pustaka untuk telaah teoritis dan data pemberitaan yang bersumber dari media, terutama media online internet yang mampu menyuguhkan data aktual dari kawasan Kintamani.
\end{abstract}

Kata kunci: lapangan golf, Kintamani Bali, pariwisata berkelanjutan, peran serta pemerintah 


\title{
PENDAHULUAN
}

Tak dapat dipungkiri lagi bahwa industri pariwisata sudah sangat berkembang di banyak negara. Hal ini seperti yang dikemukakan dalam laporan World Tourism Organization, bahwa jumlah wisatawan dunia dari 1960 sebesar 69 juta orang meningkat tajam menjadi 664 juta orang pada 1999. Di banyak kesempatan, pariwisata terbukti memberikan kontribusi pada kemajuan suatu negara terutama dalam hal penerimaan devisa. Selama dekade 1980-an sampai 1990-an, jumlah wisatawan dunia meningkat 55,8\% dengan tingkat pertumbuhan rata-rata per tahun adalah 4,5\%. Dari jumlah itu, penerimaan di sektor pariwisata tumbuh sebesar 105,5\% dari 221,2 milyar dolar (USD) sampai 454,6 milyar dolar (USD). Jika dirata-rata, terjadi peningkatan penerimaan 7,5\% setahun (Diarta, 2012).

Data di atas semakin memperkuat fakta bahwa pertumbuhan pariwisata mampu memberikan dampak besar terhadap perkembangan suatu tempat. Dengan pertumbuhan ekonomi yang signifikan, banyak negara tergiur untuk merencanakan dan mengembangkan kawasan wisata yang dimiliki. Pengembangan kegiatan pariwisata pada praktiknya terdiri dari beberapa pihak yang disebut juga pelaku pariwisata. Menurut Damanik dan Weber (2006), pihak-pihak yang dapat berperan sebagai pelaku pariwisata adalah wisatawan, industri pariwisata, pendukung jasa wisata, pemerintah, masyarakat lokal, dan lembaga swadaya masyarakat. Terlaksananya pembangunan pariwisata erat kaitannya dengan kebijakan pemerintah setempat (ancillary). Hal ini disebabkan izin pembangunan memang hanya bisa dikeluarkan oleh pemerintah setempat dengan serangkaian proses legitimasi. Hal ini tidak bisa dihindarkan karena sebagai pemilik otoritas wilayah, pemerintah mempunyai kewenangan dalam hal mengatur penggunaan wilayah negara yang digunakan sebagai lahan untuk pengembangan pariwisata (Wardiyanto dan Baquini, 2010:35).

Di Kecamatan Kintamani, Kabupaten Bangli, Provinsi Bali, terdapat kawasan kaldera Batur. Tepatnya, di sejumlah tempat yang selama ini dipenuhi bekas lava yang sudah tak produktif lagi. Menurut yang dilansir dalam bisnisbali.com (27 januari 2011), tempat ini direncanakan akan dibangun lapangan golf yang diusulkan oleh Menteri Jero Wacik, dan sudah disetujui oleh kalangan anggota DPRD Bangli. Masih dari sumber yang sama, Sudiartana, anggota Fraksi Partai Demokrat DPRD Bangli mengatakan:

\begin{abstract}
"Apapun alasannya yang paling menentukan apakah rencana mega proyek tersebut akan berjalan atau hanya wacana akan ditentukan oleh dukungan dari warga sekitar dalam hal ini warga Desa Batur dan desa-desa lain yang akan menjadi lokasi pembangunan lapangan golf tersebut... masalah yang paling mendasar adalah tata ruang Kintamani mengingat selama ini status Kintamani hanya sebatas daerah stop over wisata.” (Bisnis Bali, 27 Januari 2011)
\end{abstract}

Objek wisata yang ada di Kintamani terkenal akan wisata gunung dan danau Batur. Menurut data geografis dalam Dwi (2010), objek wisata kawasan Batur berada pada ketinggian 900 meter di atas permukaan laut dengan suhu udara sejuk pada siang hari dan dingin pada malam hari. Gunung berapi aktif dan sangat berpengaruh di wilayah Kintamani adalah Gunung Batur. Geologi Kintamani juga sangat dipengaruhi geologi gunung Batur. Gunung ini pernah meletus pada 1917, yang erupsinya megakibatkan ribuan korban dan merusak banyak bangunan, terutama candi, yang ada di sekitarnya. Gunung Api Batur memiliki dua kaldera, yaitu kaldera luar dan kaldera dalam. Di salah satu kaldera inilah direncanakan akan dibangun lapangan golf.

Seperti yang sudah disebutkan, merencanakan dan mengembangkan suatu kawasan pariwisata tidaklah mudah karena perencanaan pariwisata meliputi proses yang kompleks dengan mempertimbangkan berbagai pihak. Dengan memerhatikan betapa pentingnya perencanaan pariwisata dalam hal keberlanjutan pariwisata, mutlak diperlukan penanganan yang mempunyai pandangan jangka panjang yang dapat memperhitungkan dampak pembangunan, tidak hanya secara ekonomi tetapi juga dampak secara sosial, budaya, dan alam lingkungan. Hal itu disebabkan aspek-aspek 
tersebut merupakan hal penting yang patut diperhatikan menuju pariwisata yang berkelanjutan. Dalam penelitian ini, akan dibahas mengenai pentingnya peran pemerintah dalam perencanaan pariwisata berdasarkan konsep pariwisata berkelanjutan dengan tetap memerhatikan kepentingan masyarakat setempat.

\section{METODE PENELITIAN}

Penelitian ini merupakan kualitatif deskriptif yang dimulai dari pengumpulan data, analisis data, dan interpretasi data (Maman, 2002:3). Berhubungan dengan tema yang diangkat, penelitian ini didukung oleh kajian pustaka untuk telaah teoretis. Selain itu, diperlukan juga data pemberitaan yang bersumber dari media, terutama media online internet yang dapat menyuguhkan data aktual dari kawasan Kintamani tersebut.

\section{HASIL DAN PEMBAHASAN}

Pariwisata pada praktiknya merupakan sektor multidimensi karena di dalamnya terdapat halhal yang berhubungan satu sama lain. Dimensi-dimensi tersebut antara lain dimensi ekonomi, sosial, budaya, dan lingkungan. Agar hal-hal tersebut dapat sama-sama diperhatikan dan tidak bersinggungan, dibutuhkan suatu perencanaan yang mumpuni yang dapat menjawab tantangan masa depan sebuah kawasan pariwisata.

Hal-hal yang mendasari pentingnya suatu perencanaan pariwisata adalah: fenomena pariwisata makin kompleks dari yang pernah terpikir sebelumnya; pariwisata berdampak positif dan negative; pariwisata makin kompetitif dan promosi destinasi wisata makin gencar; pariwisata bisa berakibat buruk pada sumber daya alam dan budaya; dan pariwisata memengaruhi semua orang dalam komunitas tertentu dan semua yang terlibat dalam pariwisata perlu berpartisipasi dalam proses perencanaan pariwisata (Wardianto \& Baquini, 2010:43).

Beberapa definisi muncul untuk menjelaskan arti perencanaan pariwisata itu sendiri. D.Getz (1987) dalam Wardiyanto dan Baquini (2010) mendefinisikan perencanaan pariwisata sebagai sebuah proses, berdasarkan penelitian dan evaluasi, yang bertujuan untuk mengoptimalkan potensi kontribusi pariwisata untuk kesejahteraan manusia dan kualitas lingkungan. Konsep perencanaan memiliki banyak makna sesuai dengan pandangan masing-masing ahli dan sampai sekarang pun belum terdapat satu batasan yang dapat diterima secara umum (Wardiyanto \& Baquini, 2010:41).

Masih menurut Wardiyanto dan Baquini, pengertian atau batasan perencanaan tersebut antara lain sebagai berikut: pertama, perencanaan adalah suatu proses mempersiapkan secara sistematis kegiatan-kegiatan yang dilakukan untuk mencapai suatu tujuan tertentu. Oleh karena itu, pada hakikatnya terdapat pada setiap jenis usaha manusia. Kedua, perencanaan merupakan suatu upaya penyusunan program baik program yang sifatnya umum maupun yang spesifik, baik jangka pendek maupun jangka panjang. Ketiga, perencanaan sebagai analisis kebijakan (Planning as Policy Analysis) yaitu merupakan tradisi yang diilhami oleh logika-logika berpikir ilmu manajemen, administrasi publik, kebangkitan kembali ekonomi neoklasik, dan teknologi informasi yang disebut sibernetika.

Sebagaimana dinyatakan sebelumnya, bahwa rencana pariwisata yang disusun dengan baik benar-benar memerhatikan semua aspek yang terkait. Sehingga dalam menyusun rencana pariwisata, pengembang pariwisata harus dapat memebrikan jaminan bahwa rumusan rencana pariwisata itu benar-benar dapat dilaksanakan dengan optimal. Yoeti (2008) dalam Baquini menyatakan bahwa ada sembilan prinsip yang perlu diikuti oleh pengembang pariwisata sebagai pedoman dasar untuk menyusun rencana pariwisata. 
Sembilan prinsip tersebut, yaitu: pertama, perencanaan pengembangan pariiwsata merupakan suatu kesatuan dengan pembangunan regional maupun nasional dari pembangunan ekonomi negara. Oleh karena itu, perencanaan pengembangan pariwisata hendaknya termasuk dalam kerangka pembangunan nasional suatu negara. Kedua, perencanaan pengembangan pariwisata perlu menggunakan pendekatan terpadu dengan sektor-sektor lain yang terkait. Hal ini terkait dengan karakteristik pariwisata yang bersifat multiaspek. Pariwisata tidak dapat berlangsung secara baik dan berkelanjutan jika tidak mempertimbangkan semua aspek yang terkait. Ketiga, perencanaan pengembangan pariwisata perlu di bawah koordinasi perencanaan fisik daerah/negara secara keseluruhan. Koordinasi ini diperlukan supaya tidak terjadi berbagai permasalahan wilayah yang mungkin timbul dalam pengembangan pariwisata daerah.

Kemudian, keempat, perencanaan pengembangan pariwisata perlu didasarkan pada studi yang khusus dibuat secara khusus untuk pengembangan pariwisata dengan memerhatikan perlindungan terhadap lingkungan hidup, alam, dan budaya di sekitarnya. Kelima, perencanan fisisk harus didasarkan pada penelitian yang sesuai dengan lingkungan alam sekitar dengan memerhatikan faktorfaktor geografi yang lebih luas tidak hanya dari segi administratif saja. Keenam, perencanaan dan penelitian yang dilakukan harus memerhatikan masalah kelestarian ekologi. Kelestarian ini merupakan salah satu prasarat yang harus dipenuhi supaya pariwisata dapat berlangsung secara berkelanjutan.

Lalu, ketujuh, perencanaan dan pengembangan pariwisata harus memerhatikan dampak sosial yang mungkin ditimbulkan supaya pengembangan pariwsata tidak mendapatkan resistensi karena terjadi konflik sosial yang mungkin ditimbulkan. Kedelapan, pada daerah perkotaan dan daerah industri, perlu direncanakan fasilitas hiburan yang disebut pre-urban. Terakhir, kesembilan, perencanaan pengembangan pariwisata harus didasarkan pada kepentingan peningkatan kesejahteraan masyarakat tanpa membedakan suku, agama, ras, golongan maupun bangsa.

\section{Peran Serta Pemerintah dalam Pengembangan Perencanaan Pariwisata}

Pemerintah memiliki otoritas untuk menetapkan semua keputusan strategis dalam hal pembangunan pariwisata. Suatu perencanaan yang akan atau sudah dibuat sangat mungkin dipengaruhi secara politis oleh kebijakan pemerintah. Damanik dan Weber (2006) menyatakan bahwa dalam hal pengembangan pariwisata, pemerintah dapat memainkan peran/bahkan memiliki tanggung jawab dalam hal sebagai berikut.

Peraturan tata guna lahan pengembangan kawasan pariwisata; pembangunan pariwisata sangat terkait erat dengan pemanfaatan lahan sebagai tempat pengembangan pariwisata. Oleh karena itu, diperlukan pengaturan mengenai penggunanan lahan agar dalam pengembangan pariwisata tidak terjadi masalah sosial. Perlindungan terhadap lingkungan alam dan budaya; salah satu dari ukuran keberhasilan pengembangan pariwisata adalah terjaminnya kelestarian sumber daya yang menjadi daya tarik wisata. Terkait dengan upaya pengembangan pariwisata berkelanjutan, maka kelestarian lingkungan alam dan budaya yang menjadi sumber daya pariwisata harus menjadi prioritas. Penyediaan infrastruktur pariwisata; pemerintah juga memiliki kewenangan dan tanggung jawab dalam hal penyediaan infrastruktur pariwisata, karena masalah ini juga memiliki keterkaitan dengan wilayah/daerah. Kebijakan fasilitas fiskal, pajak, kredit dan ijin usaha; negara memiliki hak untuk merumuskan kebijakan terkait dengan semua masalah tersebut yang mempunyai dampak sangat luas. Keamanan dan kenyamanan berwisata; pemerintah harus dapat memberikan jaminan keamanan ini pada masyarakat maupun wisatawan yang datang. Jaminan kesehatan; isu mengenai kesehatan ini sangat besar pengaruhnya terhadap pembuatan keputusan wisatawan, dan hal ini merupakan wacana pariwisata internasional. Penguatan kelembagaan pariwisata; karena luasnya cakupan pariwisata, pengembangan pariwisata tidak akan bisa dilaksanakan secara sendiri oleh pengembang pariwisata tanpa melibatkan pihak lain. Pendampingan dan promosi pariwisata; pemerintah memiliki tanggung jawab dalam memperkenalkan produk wisata kepada negara lain. Dalam pelaksanaannya bisa dilakukan sendiri oleh pemerintah maupun bekerja sama dengan pihak pengusaha pariwisata. Regulasi 
persaingan usaha; supaya terjamin adanya persaingan yang baik, diperlukan suatu regulasi. Regulasi inilah yang menjadi kewenangan pemerintah untuk membuatnya. Pengembangan sumber daya manusia; pemerintah punya peran sangat penting dalam hal ini, misalnya dalam membuat aturan mengenai tata cara pendidikan yang harus dilaksanakan oleh lembaga pendidikan khusus pariwisata.

Dalam tatanan politis, pemerintah selain memegang kunci terhadap realisasi pembangunan dari perencanaan pariwisata yang sudah dibuat, juga menduduki posisi krusial dalam hal penentuan kebijakan, penjaminan kesejahteraan masyarakat, dan keberlangsungan alam dan budaya. Seyogianya, pemerintah daerah di Kabupaten Bangli berpihak kepada rakyat dan memerhatikan kondisi lingkungan alam tersebut untuk membangun manifestasi kepariwisataan. Perencanaan yang baik adalah perencanaan yang meminimalkan kemungkinan dampak yang akan terjadi. Hal ini akan dibahas lebih lanjut dalam pendekatan pembangunan pariwisata berkelanjutan berikut ini.

\section{Pendekatan Pembangunan Pariwisata Berkelanjutan dan Konsep Daya Dukung}

Pembangunan pariwisata akan selalu mempunyai dampak baik dan buruk. Upaya dilakukan untuk menghasilkan hasil yang baik dan menjauhkan dari dampak buruk. Dalam hal ini, penyiapan tata ruang dan pemberdayaan masyarakat yang tinggal di sekitar objek wisata perlu menjadi perhatian dari para pengembang pariwisata supaya pariwisata dapat berkembang secara baik dan berlangsung secara berkelanjutan. Hal ini seperti yang dikemukakan oleh Wardiyanto \& Baquini (2010:69) mengenai pengembangan pariwisata berkelanjutan yang menghendaki ketaatan pada azas-azas perencanaan pariwisata. Azas-azas tersebut adalah: Diterima secara kultural, dalam hal ini pengembangan pariwisata justru diharapkan dapat menjaga kelestarian budaya lokal, terutama yang dapat menjadi daya tarik wisata; Layak secara ekonomi; pelaksanaan proyek pengembangan pariwisata perlu dijaga supaya benar-benar dapat memberikan keuntungan ekonomi, baik bagi pelaksananya maupun bagi masyarakat setempat maupun keuntungan bagi pemerintah bukannya justru merugikan pihak-pihak yang terlibat; Berwawasan lingkungan, supaya pariwisata dapat berlangsung secara berkelanjutan pengembang pariwisata harus dapat memberikan jaminan bahwa pengembangan pariwisata tidak merusak lingkungan alam sekitar objek dan daya tarik wisata.

Dalam perencanaan pariwisata, aspek daya dukung menjadi sangat penting jika ingin pembangunan yang bersifat berkelanjutan. Daya dukung wisata menurut Cooper (2008:95) sebagai konsep yang luas dan bersifat dinamis. Daya dukung sebuah kawasan wisata didefinisikan sebagai level kehadiran wisatawan yang menimbulkan dampak pada masyarakat setempat, lingkungan, dan ekonomi yang masih dapat ditoleransi baik oleh masyarakat maupun wisatawan itu sendiri dan memberikan jaminan sustainability pada masa mendatang. Cooper (2008:95) lebih memberi tekanan pada kehadiran wisatawan daripada jumlah wisatawan karena menurutnya level kehadiran lebih tepat dipakai sebagai pendekatan bagi sejumlah faktor seperti lama tinggal (length of stay), karakteristik wisatawan, konsentrasi wisatawan pada lokasi geografis tertentu dan derajat musiman kunjungan wisatawan.

Konsep daya dukung pun dapat dikategorikan menurut Cooper (2008) menjadi: daya dukung fisik, daya dukung ekologi, daya dukung social, dan daya dukung ekonomi. Cooper menjelaskan dalam bukunya berjudul bahwa hakikinya daya dukung adalah kemampuan suatu situs atau daerah menggerakkan kegiatan pariwisata tanpa kerusakan.

"Carrying capacity, in the context of tourism in general, refers to the ability of site or region to absorb tourism use without deteriorating."

Secara umum, pembangunan pariwisata mampu mengasilkan dampak negatif maupun positif dalam bidang ekonomi, politik, sosial dan kultur, lingkungan \& ekologi (Cooper, et al, 2008). Untuk mendapatkan dampak positif, pengembangan suatu objek wisata memerlukan perencanaan yang baik. Perencanaan pengembangan pariwisata harus diimbangi dengan analisis carrying capacity agar 
nantinya pengembangan tidak memunculkan dampak-dampak yang negatif. Hall dan Stephen (2006:114) menguraikan dampak-dampak negatif pengembangan pariwisata yang tidak diimbangi dengan konsep daya dukung sebagai berikut. Pertama, dampak terhadap lingkungan disebabkan ketidaktahuan dalam menentukan dan memelihara jumlah turis yang tepat untuk mengunjungi suatu objek wisata. Kedua, dampak terhadap komunitas sosial terjadi pada kehidupan masyarakat di sekitar daerah tujuan wisata maupun kepada turis yang melakukan kunjungan wisata. Ketiga, bocornya keuntungan yang diperoleh karena kecilnya pendapatan dari pariwisata yang dapat dirasakan langsung oleh masyarakat sekitar objek wisata. Hal ini membuat masyarakat setempat tidak terlalu antusias terhadap pengembangan lebih lanjut.

Daya dukung sumber daya yang berlebihan atau terlampaui akan berdampak pada sumber daya yang lain. Hal ini dikhawatirkan akan terjadi eksploitasi yang tidak sejalan dengan daya dukung suatu destinasi wisata. Sehingga pada akhirnya dibutuhkan analisis daya dukung yang akurat untuk mendapatkan kebijakan dalam merencanakan pembangunan pariwisata agar mendapatkan manfaat dari kaidah pariwisata keberlanjutan.

\section{SIMPULAN}

Secara umum, pembangunan pariwisata mampu mengasilkan dampak negatif maupun positif dalam bidang ekonomi, politik, sosial dan kultur, lingkungan dan ekologi. Menilai dampak yang mungkin timbul dari pembangunan dan masalah sumber daya yang akan dihadapi merupakan bagian dari proses perencanaan pariwisata.

Dengan memerhatikan aspek keberlanjutan dalam perencanaan pembangunan pariwisata berarti juga menghindari atau meminimalkan dampak yang terjadi karena di situ letak suksesnya suatu perencanaan. Maka agar nantinya hasil pembangunan objek wisata lapangan golf di Kintamani dapat bertahan, prinsip-prinsip berkelanjutan adalah yang paling tepat untuk diaplikasikan berikut dengan analisis daya dukung yang secara teknis memfasilitasi perencanaan pembangunan berkelanjutan. Tentunya prinsip berkelanjutan di sini adalah juga dengan memerhatikan kepentingan masyarakat setempat. Dalam skema perencanaan pembuatan lapangan golf di daerah Kintamani diperlukan dukungan dari seluruh komponen masyarakat sekitar agar pembangunan ini dapat berjalan dengan baik.

Secara politis, pemerintah mempunyai andil besar dalam realisasi ideologi tersebut. Pemerintah menyentuh hampir semua lapisan stakeholder seperti masyarakat lokal, pihak pengembang, industri, wisatawan, dan lain-lain. Sehingga dalam posisi strategis ini, hal itu merupakan tugas dan tanggung jawab pemerintah untuk dapat menjembatani aspirasi sosial masyarakat dan kebutuhan akan keseimbangan ekologis atau sumber daya alam setempat. Selain pemerintah pusat, pemerintah daerah juga memiliki peran penting dalam proyek pembangunan seperti yang diamanatkan oleh otonomi daerah. Kemudian pemerintah daerah menjadi harapan untuk mengontrol dan meninjau kembali rencana pembangunan dengan menganalisis daya dukung berpendekatan pariwisata berkelanjutan yang dapat mencegah daerah Kintamani dari dampak pembangunan yang merusak. 


\section{DAFTAR PUSTAKA}

Bisnis Bali. (27 Januari 2011). DPRD Bangli Dukung Lapangan Golf Batur. Diakses 11 Januari 2013 dari www.bisnisbali.com/2011/01/27/news/bisnisumum/hyu.html.

Cooper et al. (2008). An Introduction: Tourism and Principles, Fourth Edition Published. England: Pearson Education.

Damanik, J., Weber, H. (2006). Eco-tourism Planning: Theory to Application. Yogyakarta: Andi.

Dwi, I. (7 Januari 2010). Kondisi Geografi Kintamani. Diakses 12 Januari 2013 dari www.onegeo.blogspot.com/2010/01/kondisi-geografi-kintamani.html.

Hall, C. M., Page, S. (2006). The Geography Of Tourism And Recreation: Environment, Place And Space.Third Edition. USA: Routledge.

Wardiyanto., Baquini. (2010). Perencanaan dan Pengembangan Pariwisata. Bandung: Lubuk Agung.

Yoeti, O. (2008). Perencanaan dan Pengembangan Pariwisata. Jakarta: Pradnya Paramita. 